\title{
Organizational and economic reserves of improving the sheep breeding industry competitiveness
}

Scientific problem. The transition of economy to a market relations and the subsequent transformation intended to increase the competitiveness of agricultural production and more fully utilize its potential. However, the imbalance of organizational and economic reform mechanisms due to the growing problems of production and financial condition resource supporting of considerable part of farms, reducing their ability to pay, the breaking-off of economic relations, ineffective government programs of supporting industries, including sheep breeding. As a result, in the industry with the start of transformational changes was outlined a trend towards reduction of livestock, rising production costs and so on. Most sheep breeding companies turned out in a crisis, which showed itself primarily in the unprofitableness and the low competitiveness of products.

Analysis of recent researches and publications. The works of Ivanov [2], Zharuk [1], Mesel-Veselyak [5], Morozov [6], Sokolov [10], Parhomets [8], Topiha [11], Turinskiy [12], Shelest [14], Shynkarenko [15] and others are dedicated to development of sheep industry and increase of its competitiveness. However, researches should be done on the elimination of the main causes of destabilization of the industry and there is an objective need to develop organizational and economic measures to improve its competitiveness. Noticed above becomes particularly urgent with signing an Association Agreement with the EU by Ukraine.

The objective of the article is to carry out an economic analysis of the factors that shape competitiveness of sheep industry and to offer

() O.A. Kozak, I.M. Bezhenar, 2015 organizational and economic reserves of its increase in Ukraine.

Statement of the main results of the study. Sheep breeding has always been traditional for Ukraine industry, offering the widest range of products (14 species), among other sectors of agriculture. A significant negative factor that influenced the development of the industry in the transition to a market economy was the refusal of the military and educational institutions from quotas for the purchase of wool for sewing military uniforms. Lack of market for wool, lamb, sheepskins, sheep breeding and sheepskin led to a reduction in the sheep livestock, the decrease in production and sales sector, decoupling in production, processing, deterioration of material and technical equipment, scientific software, unprofitableness of majority of producers shepherd products [3]. In 2013 the share of the gross production of animal husbandry Ukraine was $0.2 \%$, which is six times less than in 1990.

Analysis of the data indicates redistribution between categories of sheep farms in favor of the private peasant farmes caused a significant reduction in its agricultural enterprises. If in 1990 the public sector held $90.7 \%$ of livestock, in 2013 its share was only $22.8 \%$. From 1049 shepherd enterprises: $37.8 \%$ maintain less than 49 head, 15.8 - 99 head, $16.5 \%$ - from 100 to 199 head, $25.3 \%$ from 200 to 999 head, $4.6 \%$ to 1999 head. More than 1999 sheep head held only 15 enterprises or $1.4 \%$. The average size of farms producing lamb for the last 5 years is 276 head, wool - 481 head $[1,6,8,12]$.

In sheep breeding, as in other branches of animal husbandry productivity and economic efficiency depend on the structure of the herd, primarily on the proportion of ewes in it. This 
makes it possible to solve the problem of growth of sheep livestock and increase the production sector, depending on demand. Farms specializing in growing sheep to produce lamb, hold at least $70-75 \%$ of females in the structure of the herd, in the production of wool - 40-45\%.

Today extensively herd reproduction is run, fertility ewes on average in Ukraine amounted to 72 lambs per 100 ewes (the norm on average 120$150 \%$ ), which makes it impossible in the short term to restore the number of sheep in the state to the level of 5.6 million heads. Academician Ivanov emphasized that the intensive development of sheep is not only in increasing productivity of sheep, but the intensification of the flocks reproduction system, use of cultural meat and wool sheep [2]. One of the provisions intensification of sheep in a market economy is to increase the period of productive use of ewes, which can be achieved through the rapid introduction of yearling ewes in exploitation, and by extension of the period of its productive use [14].

Ukraine has a sheep genetic potential with different directions of productivity: fine-fleeced, half- fme-fleeced, rough woolen and astrakhan sheep are bred in all naturally economic areas [15]. Economic evaluation of sheep breeds is largely determined by their market competitiveness of products. Despite the fact that over the last decade, the number of sheep decreased significantly, the genetic potential of pedigree sheep in pedigree sheep breeding farm not only preserved, but also enriched thanks to the high scientific backup selection. Wool clip per sheep remained at the 1990 level and the dynamics of years $2,9-3,6 \mathrm{~kg}$.

Negative factors of the sheep industry development led to the fact that contentment of the need in physical wool is less than $17 \%$. An- nually per capita produces about 90 grams of pure wool against the minimum requirements for the rational norms - $200 \mathrm{~g}$. In 2013 per capita produced about 48 grams of lamb with a minimum need of $0,6-2 \mathrm{~kg}$. For comparison, in New Zealand the figure was in $2009-30.5 \mathrm{~kg}$, Australia - $20 \mathrm{~kg}$, Greece - $14.0 \mathrm{~kg}$ [1]. According to statistics the share of lamb meat resources in Ukraine significantly inferior to other types of meat and makes $1.9 \%$. Because of the unresolved problems of the organization of regional slaughter enterprises of farm animals, including sheep, public and private enterprises have to slaughter animals in home conditions. All this reduces product quality.

Ukraine's foreign trade products of sheep breeding are characterized by instability and the predominance of imports over exports (in 2013 imported wool in 8.7 times more than exported, lamb - in 46.4 times) [17-20]. Wool trade is characterized by frequent changes of countriesbuyer and countries-seller and a large their number. Despite this, in the future, Ukraine could become a powerful exporter of mutton to EU countries and the Middle East through the territorial proximity to the European market and dissatisfied demand for these products. It should be noted that provided considerable quota for the supply of lamb for Ukraine by the EU. Constraining factor for export at present is the lack of quality certification in accordance with international standards.

The period of reforms coincided in time with new global trends in the industry, including production reorientation direction of specialization (wool, meat, milk) in Ukraine showed that effective indices are increasing with producing of lamb and sheep's milk, and the most profitable is the complex use products (Table 1).

\section{Effectiveness of sheep production in different areas of specialization}

\begin{tabular}{|c|c|c|c|c|c|c|c|c|}
\hline \multirow{3}{*}{ Production } & \multicolumn{6}{|c|}{ Areas of specialization } & \multirow{2}{*}{\multicolumn{2}{|c|}{ Complex use products }} \\
\hline & \multicolumn{2}{|c|}{ wool } & \multicolumn{2}{|c|}{ meat } & \multicolumn{2}{|c|}{ milk } & & \\
\hline & Q-ty & Price, UAH & Q-ty & Price, UAH & Q-ty & Price, UAH & Q-ty & Price, UAH \\
\hline Wool, kg & 3 & 48 & 2,3 & 9,2 & 2,3 & 8,1 & 2,3 & 8,1 \\
\hline Sheepskin, pc & 1 & 12 & 1 & 12 & 1 & 12 & 1 & 12 \\
\hline Meat, kg & 10 & 250 & 30 & 750 & 15 & 375 & 18 & 450 \\
\hline Brynza, kg & - & - & - & - & 10 & 350 & 10 & 350 \\
\hline Other products, $\mathrm{kg}$ & 1 & 2,8 & 1 & 2,8 & 1 & 2,8 & 1 & 2,8 \\
\hline $\begin{array}{l}\text { Obtained gross products } \\
\text { of } 1 \text { sheep, UAH }\end{array}$ & & 312,8 & & 774 & & 747,9 & & 822,9 \\
\hline $\begin{array}{l}\text { The cost of one sheep } \\
\text { maintaining, UAH }\end{array}$ & & 690 & & 690 & & 690 & & 690 \\
\hline Profit per 1 sheep, UAH & & $-377,2$ & & 84 & & 57,9 & & 132,9 \\
\hline
\end{tabular}

Source: Calculated by the authors. 
So, one of reserves of improving competitiveness in existing conditions may be modified intra-industry specialization.

The most important element of sheep breeding development in Ukraine and increase its competitiveness, according to the state agricultural policy objectives and strategies for socioeconomic development should be the strengthening of public support at national and regional levels with the tools of regulation [9]. Government support in the form of financial and material assistance or partial compensation costs (public investments, tax breaks and financing, use of extra-budgetary sources for construction works, purchase of equipment, agricultural and special equipment) requires firstly in the initial stages of the sheep farms to enable enterprises expansion of existing production capacity.
The primary measure is the adoption of " The program of sheep breeding industry in 2015-2020 years.", which would increase the number of sheep to 1.8 million heads, lamb production to 44.4 thousand tons, wool to 6.3 thousand tons, milk to 9.5 ths. tons. According to L. Shelest, improving material interest requires allocation of purpose-oriented subsidies (for products, purchasing of pedigree sheep, etc.), as well as soft loans to carry out breeding, scientific researches, etc .. Without state support domestic producers of sheep products. It is difficult to compete on global market with countries where there is a practice of providing subsidies [13].

Improving the competitiveness of sheep products largely depends on the measures to be applied at the enterprise level (Table 2).

\section{Areas of increasing the competitiveness of sheep production at the macro level}

\begin{tabular}{|c|c|}
\hline Types of measures & Meaning \\
\hline $\begin{array}{l}\text { Organizational } \\
\text { and Production }\end{array}$ & 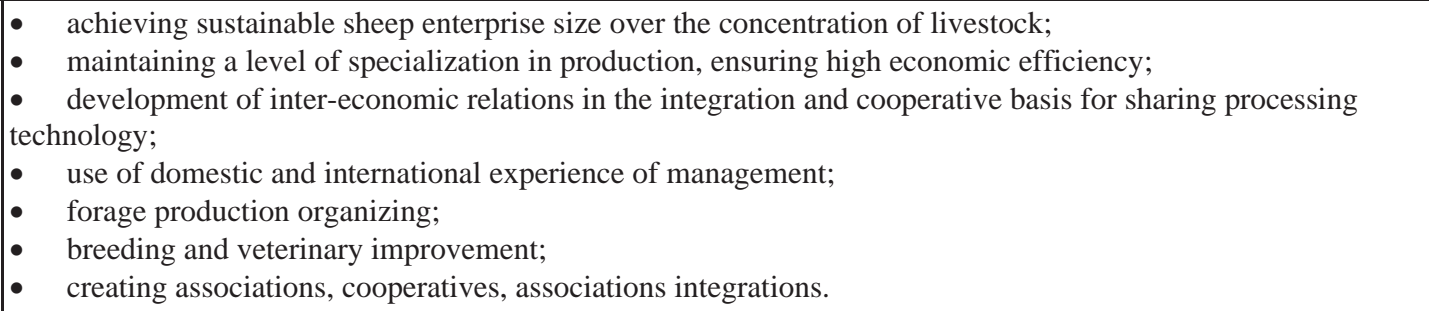 \\
\hline Technological & $\begin{array}{l}\text { - use of new resource- and energy saving technologies in the stages of production, storage, transport; } \\
\text { introduction in the production stage of scientific researches, the implementation of innovative projects for } \\
\text { mechanization and automation of production processes ; } \\
\text { - improvement of maintenance, reproduction, feeding, veterinary protection. }\end{array}$ \\
\hline Economic & $\begin{array}{l}\text { reducing the cost of production; } \\
\text { attracting investment (including foreign); } \\
\text { increasing profitability; } \\
\text { more efficient use of financial and material resources; } \\
\text { occupation competitive position on the market. }\end{array}$ \\
\hline Social & $\begin{array}{l}\text { increasing productivity; } \\
\text { qualification of staff; } \\
\text { - } \quad \text { social security for workers in the industry; } \\
\text { improving working conditions for employees and solving their social problems/ }\end{array}$ \\
\hline $\begin{array}{l}\text { Organiza-tional } \\
\text { and management }\end{array}$ & $\begin{array}{l}\text { - diversification of sheep production including world experience -conversion of sheep enterprises on produc- } \\
\text { tion of milk and lamb and shepherd's diversification of products (eg · packing and packaging for retailers of lamb } \\
\text { carcasses, semi-carcasses, cuts, making a variety of cheese from sheep's milk); } \\
\text { - quality management through standardization of products, the introduction of standards and quality control } \\
\text { standards for the products of sheep; } \\
\text { - improvement of quality control of raw materials, semi-finished and finished products; } \\
\text { - improving the organizational management system for sheep enterprises (using scientifically-founded meth- } \\
\text { ods of strategic management); } \\
\text { - development of marketing measures in the company - market research forecasting sales, creating logos, } \\
\text { ordering database about the competitors, implementation of marketing measures and advertisement to promote } \\
\text { products, participation in fairs and exhibitions; } \\
\text { - Formation of infrastructure provision of production and sales (the presence or warehouses or refrigeration } \\
\text { equipment for storage); } \\
\text { - Using the tools of logistics, improvement of transport and sales infrastructure. }\end{array}$ \\
\hline
\end{tabular}

Source: Generated by the authors. 
It is important to strengthen the role of civil society organizations. Ukraine has a specialized Ukrainian public organization "Association of sheep and goat breeders" - voluntary association of sheep products producers, which promotes sheep breeding. The purpose of the organization to assist in acquiring, implementing goats and sheep, including breeding, feed, equipment for animal production and processing sheep products, inform import features, help in finding potential buyers-exporters of animals from abroad (Germany, Austria, etc.), provides advice on obtaining permits for export, cooperation with veterinary inspection survey in terms of potential exporters etc [7]. In the future, expected to attract more manufacturers to this public organization to exchange experiences, lobbying the interests of producers and a greater impact on the government, the voluntary entry and exit and equality of all participants.

In areas of intensive sheep farming (steppe zone, the Carpathian region), it is reasonable to create or improve the work of existing information and consultation structures - regional associations of sheep products (eg, public association "Vivcharstvo Khersonschiny", "Association of Zakarpatta sheep breeders" and advisory services . Activities such associations should be based on trusting relationships with producers (agricultural, farm and personal farming) and will provide by professional staff economic, technological consultation promoting through seminars, presentations, dissemination of information, methodical, educational and scientific materials. At the same time the current needs of farms in equipment and provided various kinds of assistance (supply of inputs, registration and identification of sheep) will be shown.

The main function of the regional associations - providing free promotion sheep products from producers to processing plants by forming large trade flows. The implementation of this function is possible with consolidated information on the number of producers, the volume of production in general and in individual economies of the region. Currently, a commodity producer is forced to find markets, this process is complex and time-consuming. Therefore, the association will be "intermediary" between producers and processors.

Creation of information and consultation structures will provide public authorities and manufacturers of production with information on products, customers, competitors, markets, dynamics and level of demand, the prices of different products, etc.[4]. Specialists of associations at the regional level will provide information on regional market places with sheep products, demand and consumer demand, etc. Thus conditions for free access to information, analysis and forecasts for all market participants will be provided (Figure).

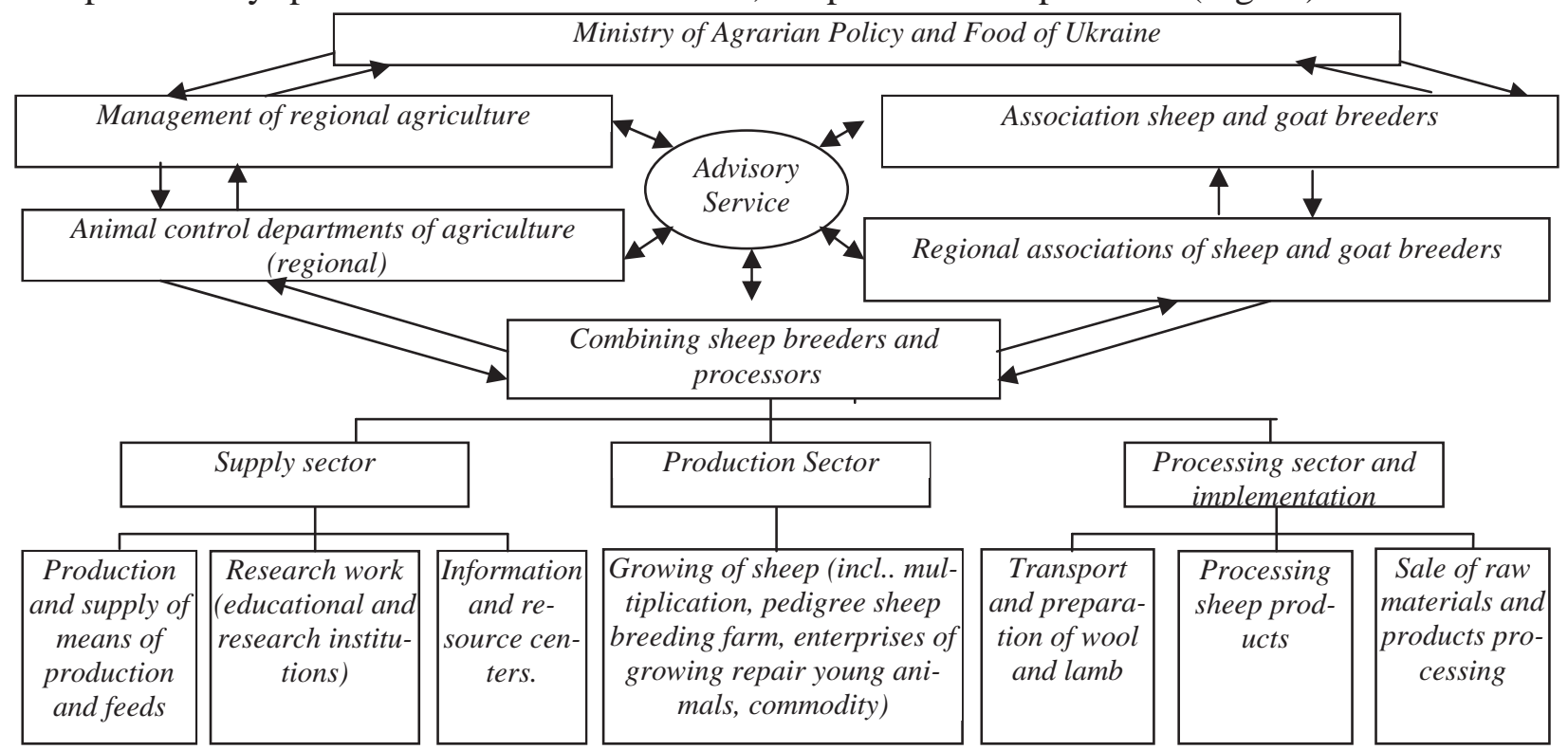

Figure. The organizational structure of the information exchange in the field of sheep breeding in the presence of regional sheep associations.

Source: Development of the authors. 
Summary of regional associations should be sent to All-Ukrainian Association, which puts it on its web-site. Also, this organization will carry out the following activities: provides information and marketing services to members of the association about development program and other legislation relating to the sheep breeding, condition, prospects, business conditions, pricing of domestic and foreign markets for the products of industry, modern ways of organizing production and methods of combating sheep diseases; inform about terms of sheep products insurance and on the taxation of producers; carry out coordination of production and processing sheep products; facilitate internship abroad and help in finding sources of investment and credit; organizing the implementation of raw materials, finished products searching marketing channels; promotion of the markets on the basis of meeting the interests of all market participants.

Conclusion. Economic indices of sheep breeding industry throughout the period of agrarian transformations have a general negative trend. The decline of the industry continues and increases internal (production of other types of livestock and crop production especially) and external (world market production of sheep products) competition. If there are many organizational and economic problems in the industry its genetic potential still is very strong. An important incentive for increasing production could be provided by the European Union quota for deliveries lamb in volumes exceeding production in the country.

Calculations have shown expediency of change of intra-industry specialization from sheep breeding to milk and meat, which generally meets international trends in the market of the product.

To increase the competitiveness of the industry will facilitate: state support in the first place, the adoption of the "Program of sheep breeding industry in 2015-2020 years", and measures applied at the enterprise level (organizational, economic, technological, economic, social, organizational and managerial).

An important role is played by civil organizations - regional associations of producers of sheep products and advisory services that will boost market sheep products.

\section{References}

1. Zharuk L.V. Analysis sheep breading competitive enterprises in market conditions / L.V. Zharuk, L.S. Shelest // Sheep: Interdepartmental thematic scientific scientific collection of articles - New Kakhovka, 2007, Vol. 34. - P. $171-176$.

2. Ivanov M.F. The course of sheep breeading. 5 publisher corrected and supplemented / M.F. Ivanov // K: State publishing of agricultural literature of USSR, 1950. - $399 \mathrm{p}$.

3. Kozak O.A. Ways of increasing the competitiveness of sheepbreeding / O.A. Kozak, I.M. Bezhenar // Vestnik of National University of Water and Environment. Economy: collection of scientific papers - Rivne: NUWE, 2014. - Vol. 1 (65). P. 175-181.

4. Ksenofontov M.M. Improving the relations information and consulting services and economic structures / M.M. Ksenofontov // Economy APK. - 2000. - № 5. - P. 9-11.

5. Mesel-Veselyak V.J. Reform of the agricultural sector of Ukraine (results, problems and solution) / V.J. Mesel-Veselyak // Materials of the interregional participants of Congress of Ukrainian scientists agricultural economists (29 January), "Organizational and economic transformation in the agricultural production" .- Lugansk: "Elton-2", 2010. - P. 19-29.

6. Moroz V.O. Sheep and goat: Textbook. / V.O. Moroz. - Stavropol: SSAU "Agrus", 2005. - 469 p.

7. The official website of the Association of sheep and goat breeder Ukraine. [Electronic resource]. - Access: http://aviku.org.ua/.

8. Parhomets M.K. The competitiveness of major sectors of agriculture in the regions of Ukraine: analysis, problems and increase / M.K. Parhomets // Ukrainian scientific production journal "Innovative Economy APK" .- Ternopil: 5'2011 [24]. - P. 93- 106

9. About state Support of Agriculture of Ukraine: Law of Ukraine from 24.06.2004 year number 1877-IV. [Electronic resource]. - Access: http://zakon4.rada.gov.ua/laws/show/1877-15.

10. Sokol O.I. Sheep breeding of Ukraine in the context of global industry development trends/ O.I. Sokol // The market economy transformation APK: collective monography in four parts. [edited P.T. Sabluk, V.J. Ambrosov, G.E. Maznyev.] Kyiv: NSC "IAE”, 2002 - Part 1. Socio-economic problems of rural development. - P. 515-524.

11. Topiha I. Improvement of methods economic evaluation of energy intensity of production of sheep / I.Topiha, L. Shelest // Animal of Ukraine. - 2001. - № 5. - P. 21-23.

12. Turinskiy V.M. The competitiveness of regions of Ukraine in the production and sales of products sheep breeding / V.M. Turinskiy, L.S. Shelest // Scientific Papers. - Kam.-Pod. 2004 - Edition 12. - P. 145-149.

13. Shelest L.S. State support of sheep breeding industry / L.S. Shelest. // Economy APK International Scientific and Production Journal. - 2010. - №5. - P. 17-22. 
14. Shelest L.S. Organization of competitive sheep breeding: monograph / L.S. Shelest - Askania Nova: Ukrainian Academy of Agrarian Sciences, Institute of Animal steppe areas of M.V. Ivanov "Askania Nova", 2008. - 208 p.

15. Shynkarenko M. Sheep breeding in the market conditions / M. Shynkarenko // Koloc. - 1995. - №19. - P. 6.

16. Marceau J. Budorcas taxicolor / J. Marceau // Animal Diversity. Web. - 2008. [Electronic resource]. - Access: http://animaldiversity.ummz.umich.edu/site/accounts/information/Budorcas taxicolor. html.

17. New Zealand sheep breeds. [Electronic resource]. - Access: http://www.teara.govt.nz/en/sheep-farming/6.

18. Philip K. Thornton Livestock production: recent trends, future prospects - 2010. [Electronic resource]. - Access: http://rstb.royalsocietypublishing.org/content/365/1554/2853

19. Sheep Farming Market Research Report (NAICS 11241) - Sep 2014. [Electronic resource]. - Access: http://www.ibisworld.com/industry/default.aspx?indid=60

20. Sheep production handbook /American Sheep Industry Association, Inc. - 2002 Edition, Vol. 7. - 1060 p.

21. The State of the World,s Animal Genetic Resources for Food and Agriculture. Edited by Barbara Rischkowsky and Dafydd Pilling //FAO, Rome, 2007. - 511 p.

The article has been received 09.07 .2015

$* * *$

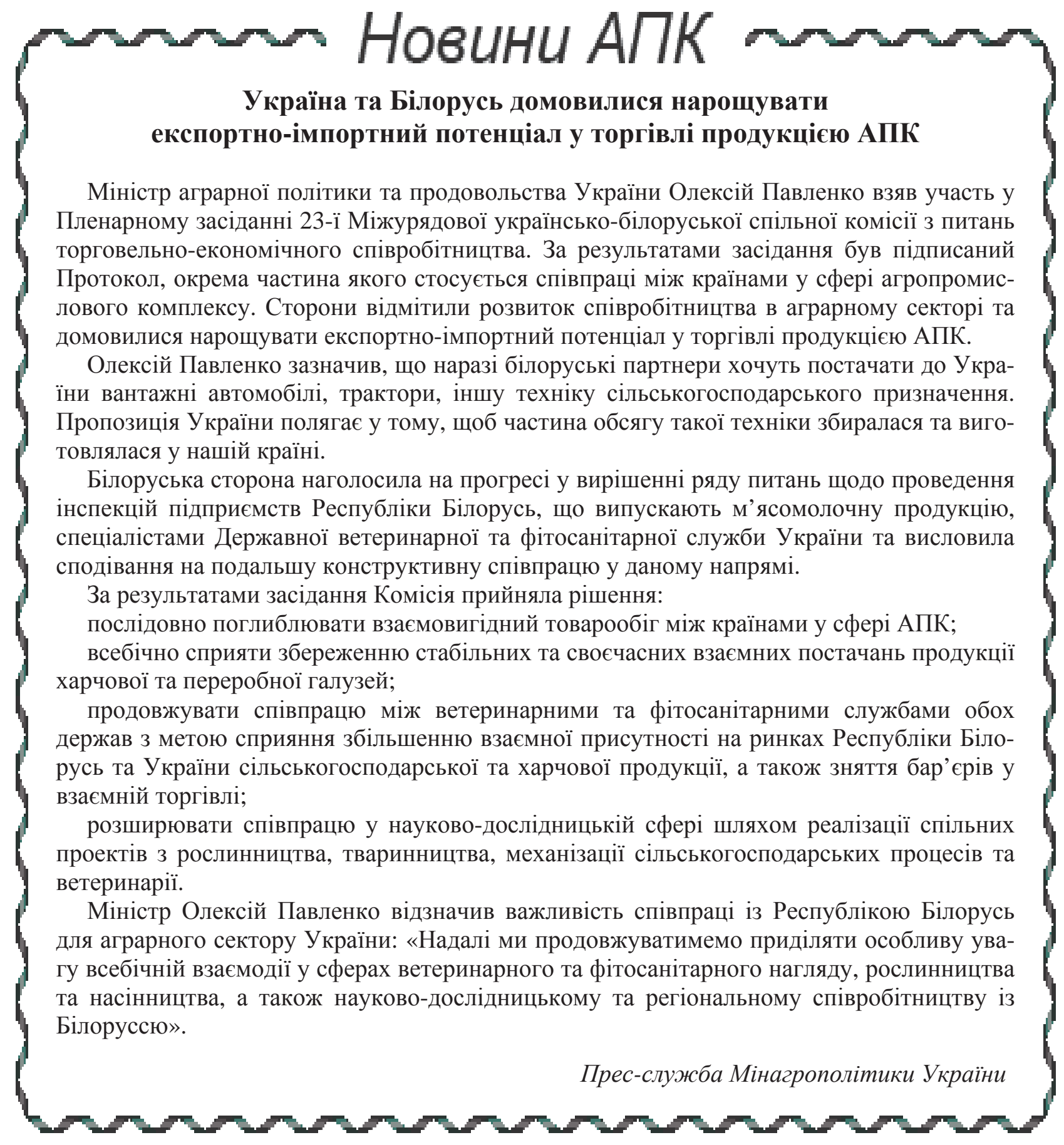

